\title{
PENGEMBANGAN EKOWISATA KAWASAN KONVERSI HUTAN MANGROVE KALIMANTAN TIMUR
}

\author{
Arwin Sanjaya \\ University Mulawarman \\ Jl. Kuaro Gn. Kelua,75119 Indonesia \\ Sarwo EddyWibowo \\ University of 17 Agustus 1945 Samarinda \\ Jl. Ir. H. Juanda No. 80, 75124, Indonesia
}

\begin{abstract}
Ecotourism is a journey that has the purpose to conserve the environment and preserve the life and also the economic of the surrounding population around of the ecotourism. It is having the responsibility for the natural area also. Ecotourism can be seen as a concept of developing sustainable tourism, ecotourism purpose is to support environmental conservation efforts and can increase community participation in its management.

Mangrove ecotourism is one of the popular ecotourism but has several problems. The problems are in its conservation activities itself. This study uses a qualitative descriptive approach and an interactive data analysis model. The results showed that the development of Ecotourism in the Mangrove Forest Conservation Area was carried out by local communities supported by the government, NGO, and the private sector through various programs that was helped by the local communities to continue and to become more productive in preserving and maintaining the natural environment of the mangrove area to be better aims in the future.

The policy and role of the institutions in the Developing of Ecotourism (Ekowisata) in Mangrove Forest Conservation Areas it could be hoped to improve and increase the living standard of local communities if it is managed properly and correctly. The role of institutions are to give many contributions and also for providing assistances and monitoring in every single of social and community activity.
\end{abstract}

Keywords: Ecotourism, tourism management, mangrove

\section{PENDAHULUAN}

Indonesia dianugerahi alam bebas yang sangat kaya beserta sumber daya yang dimiliki. Hal ini yang membuat Indonesia bagaikan bentang permadani hijau yang luas dari ujung timur ke barat. Hal ini merupakan potensi besar yang perlu dijaga dan dirawat kelestariannya agar tercipta keseimbangan alam. Tindakan manusia melalui proses merawat anugerah karunia Tuhan berupa keindahan alam ini dapat dijadikan investasi baik bagi generasi saat ini maupun generasi yang akan datang. 
Salah satu manifestasi alam Indonesia adalah pariwisata alam (Ecotourism) yang sejak lama berkembang dan menjadi sebuah kebangkitan kesadaran sebagian masyarakat untuk menjaga kelestarian alam dan mencoba untuk membangkitkan bahwa alam memiliki dampak yang sangat besar bagi berbagai sektor seperti ekonomi, politik, sosial, dan sebagainya.

Ekowisata dapat diartikan sebagai suatu perjalanan wisata yang memiliki tujuan mengonservasi lingkungan dan melestarikan kehidupan dan kesejahteraan penduduk sekitar dan memiliki bertanggung jawab pada kawasan alam. Sehingga ekowisata ini dapat dilihat sebagai suatu konsep pengembangan pariwisata yang berkelanjutan serta bertujuan untuk mendukung upaya-upaya pelestarian lingkungan dan dapat meningkatkan partisipasi masyarakat dalam pengelolaannya. Dengan melihat kompleksitas dari berbagai pengertian ekowisata dan potensi yang dimiliki oleh suatu kawasan tersebut, pengelolaan ekowisata. Kawasan mangrove harus dapat menciptakan berbagai peluang yang dapat meningkatkan pendapatan bagi masyarakat sekitar baik secara langsung maupun tidak langsung.

Penggalian potensi, nilai kawasan ekosistem mangrove dan kelestariannya merupakan prioritas utama, dengan tujuan untuk dapat mengetahui seberapa besar potensi tersebut dapat dimanfaatkan untuk meningkatkan pendapatan daerah yang berdasar prinsip-prinsip keadilan dan kemandirian sehingga pada akhimya akan meningkatkan kesejahteraan masyarakat. Oleh karena itu diperlukan penelitian tentang pengelolaan pengembangan ekowisata kawasan mangrove untuk mendukung pelestarian lingkungan pesisir yang berkelanjutan.

Hutan Mangrove memiliki kekayaan yang tak ternilai harganya. Terdapat jenis pepohonan, hewan dan tanaman lainnya yang dapat diambil kayunya, daging, buah-buahan hingga dedaunan yang berkhasiat untuk kesehatan, bahan pangan bagi manusia dan pakan bagi ternak. Mangrove sebagai karakteristik dari bentuk tanaman pantai, estuari atau muara sungai dan delta di tempat yang terlindung daerah tropis dan sub tropis sehingga merupakan ekosistem 
yang terdapat di antara daratan dan lautan dan pada kondisi yang sesuai mangrove akan membentuk hutan yang ekstensif dan produktif.

Melihat dari permasalahan dan potensi hutan Mangrove di Kalimantan Timur maka dipandang perlu langkah-langkah strategis dalam mengembangkan ekowisata hutan mangrove oleh para stakeholder guna menunjang perekonomian setempat. Selain itu kelestarian hutan mangrove tetap terjaga.

\section{KERANGKA TEORITIS}

\section{Definisi Ecotourism}

Berdasarkan dua kata eco dan tourism, yang ketika diadopsi ke dalam bahasa Indonesia menjadi kata eko dan turisme atau eko dan wisata . Makna dasar dari 2 kata tersebut dapat dijabarkan sebagai berikut , eko yang dalam bahasa Greek (Yunani) berarti rumah, dan tourism yang berarti wisata atau perjalanan. Pengertian selanjutnya oleh beberapa ahli kata Eco dapat diartikan sebagai Ecology atau Economy sehingga dari kedua kata tersebut akan memunculkan makna Wisata ekologis (Ecological Tourism ) atau Wisata Ekonomi (Economic
Tourism) dan hal ini masih terus diperdebatkan oleh para ahli mengenai makna dari kata dasar tersebut (Dirawan, 2003).

Ecotourism is responsible travel to natural areas that conserves the environment and improved the well being of local people (Hadi, 2007). Selanjutnya Hadi (2007) menyatakan bahwa prinsip-psinsip ekowisata adalah meminimalkan dampak, menumbuhkan kesadaraan lingkungan dan budaya, memberikan pengalaman positif baik kepada turis (visitors) maupun penerima (host) dan memberikan manfaat dan keberdayaan masyarakat lokal. Karakteristik ekowisata yang membedakannya dengan wisata massal/konvensional.

1. Kegiatan wisata, berkaitan dengan konservasi lingkungan. Meskipun motif ekowisata memiliki keterkaitan dengan beberapa prinsip pengembangan

2. Usaha pariwisata tidak hanya menyiapkan sekedar atraksi wisata, akan tetapi menawarkan pula peluang untuk menghargai 
lingkungan

secara

berkesinambungan.

3. Usaha pariwisata memiliki tanggung jawab ekonomi dalam pelestarian lingkungan hijau

4. Usaha pariwisata yang lebih banyak menggunakan sarana transportasi lokal, sarana akomodasi lokal, yang dikelola masyarakat setempat dan membedakan kehidupan masyarakat setempat dalam menumbuhkan pendapatan masyarakat dari berbagai kegiatan

\section{Konsep Pengembangan Ekowisata}

Meningkatkan kesadaran masyarakat mengenai lingkungan telah memberikan implikasi munculnya berbagai tuntutan di semua sektor pembangunan. Tuntutan-tuntutan tersebut telah dan akan mendorong tumbuhnya usahausaha baru, cara cara pendekatan baru dalam berbagai kegiatan baik bisnis pariwisata secara langsung yang dilakukan dunia usaha pariwisata dan usaha-usaha masyarakat dalam upaya meningkatkan taraf kesejahteraan mereka. Kondisi tersebut makin meyakinkan bahwa lingkungan bukan lagi beban, tetapi dapat dimanfaatkan untuk meningkatkan usaha-usaha ekonomi.

lingkungan mempunyai peran penting dalam usaha mendorong semua lapisan masyarakat untuk memanfaatkannya sebagai peluang bisnis, sehingga diharapkan dapat mendorong semua pihak untuk dapat menyelesaikan masalah-masalah dan mampu mendorong keikutsertaan semua unsur secara bersama-sama menanggulangi masalah lingkungan secara bersama-sama.

Menghormati hak asasi manusia bebas melakukan perjalanan wisata adalah salah satu makna yang tercantum dalam Declaration of Human Right. Manusia bebas melakukan perjalanan kemana saja di muka bumi ini. Manusia berhak menikmati apa saja yang mereka butuhkan, termasuk menikmati pengembangan ekowisata, tidak hanya mengejar kebutuhan material semata akan tetapi memiliki landasan pijak yang kokoh dalam menata, memanfaatkan dan mengembangkan ekowisata pada prinsip-prinsip pembangunan ekowisata yang berkelanjutan menjadi bagian penting dari pembangunan kepariwisataan 
berkelanjutan sebagai konsep dan pendekatan yang telah diakui secara nasional maupun internasional

\section{Pendekatan lingkungan}

Definisi maupun prinsipprinsip ekowisata mempunyai implikasi langsung kepada wisatawan dan penyedia jasa perjalanan wisatawan. Wisatawan dituntut untuk tidak hanya mempunyai kesadaran lingkungan dan kepekaan sosial budaya yang tinggi, tetapi mereka harus mampu melakukannya dalam kegiatan wisata melalui sifat-sifat empati wisatawan, digugah untuk mengeluarkan pengeluaran ekstra untuk pelestarian alam. Analisis yang mendalam terhadap pihak-pihak yang berkepentingan terhadap pelestarian dan konservasi lingkungan perlu dilakukan untuk menemu kenali pihak yang berpentingan dan memanfaatkan lingkungan sebagai bagian dari kehidupannya. Pertumbuhan ekonomi dan perubahan karakteristik psikografis dan demografis wisatawan di Negara asal, menciptakan kelompok pasar dengan penghasilan yang tinggi dan harapan yang berbeda dalam melakukan perjalanan wisata.

\section{Pendekatan partisipasi dan pemberdayaan}

Pendekatan partisipasi dan pemberdayaan masyarakat setempat pengembangan ekowisata, harus mampu menghasilkan model partisipasi masyarakat.

Partisipasi masyarakat setempat dilibatkan dalam penyusunan perencanaan sejak awal, dimana masyarakat dapat menyampaikan gagasan-gagasan yang dapat memberikan nuansa Participatory Planning, dan mendorong mereka mengembangkan gagasan murni tanpa pengendalian dan pengarahan terkendali dari pihak-pihak berkepentingan. Beberapa unsur yang mampu mendorong gagasan adalah ekonomi, konservasi, sosial, politik, regulasi lingkungan, pemberdayaan dan reklamasi lingkungan yang rusak, pemberdayaan seni budaya lokal dan lain-lain.

\section{Pendekatan sektor publik}

Peran sektor publik sangat penting dalam pembinaan otoritas untuk menyusun kebijakan dan pengendalian tentang manfaat sumber daya alam dan lingkungan, di dalamnya pemerintah memiliki 
otoritas dalam penentuan kebijakan yang berkaitan dengan program dan pembiayaan sektor pembangunan lingkungan dan kepariwisataan yang memiliki mekanisme kerjasama baik secara vertikal maupun horizontal dan struktural, dan yang tidak kalah pentingnya adalah pemerintah memiliki akses yang cukup tinggi dengan penyandang dana, seperti bank, investor dan donatur dalam negeri dan luar negeri.

\section{Pendekatan pengembangan infrastruktur}

Penyediaan infrastruktur dasar adalah merupakan kegiatan penting untuk memperkuat pengembangan ekowisata. Jalan, jembatan, air bersih, jaringan telekomunikasi, listrik dan sistem pengendalian dan pemeliharaan lingkungan, merupakan unsur-unsur fisik yang dibangun dengan cara menghindari perusakan lingkungan atau menghilangkan ranah keindahan pada lokasi ekowisata. Teknologi tinggi harus mampu menghindari kerusakan lingkungan dan kerusakan pemandangan yang bertolak belakang dengan konfigurasi alam sekitarnya.

Pendekatan pengendalian dampak ekologi pariwisata

\begin{abstract}
Pengembangan ekologi pariwisata berdampak kepada pemanfaatan sumber daya yang tersedia seperti terhadap areal yang digunakan, banyaknya energi yang terpakai, banyaknya sanitasi, polusi suara dan udara, tekanan terhadap flora dan fauna serta ketidakseimbangan lingkungan terkait dengan itu, maka perlu dirumuskan pembinaan usaha pariwisata oleh pihak-pihak yang akan melakukan monitoring lingkungan pariwisata yang didukung oleh para ahli dibidang itu, mengingat bentuk dampak lingkungan sangat berbeda-beda antara satu usaha dengan usaha lain
\end{abstract}

\section{Pendekatan Zonasi Kawasan}

\section{Ekowisata}

Zoning peletakan fasilitas dibedakan dalam tiga zonasi yaitu zona inti, zona penyangga, zona pelayanan dan zona pengembangan.

a Zona Inti : dimana atraksi/daya tarik wisata utama ekowisata.

b Zona Antara (Buffer Zone) : dimana kekuatan daya tarik ekowisata dipertahankan sebagai ciri-ciri dan karakteristik ekowisata yaitu mendasarkan lingkungan sebagai yang harus 
dihindari dari pembangunan dan pengembangan unsur-unsur teknologi lain yang akan merusak dan menurunkan daya dukung lingkungan dan tidak sepadan dengan ekowisata.

c Zona Pelayanan : wilayah yang dapat dikembangkan berbagai fasilitas yang dibutuhkan wisatawan, sepadan dengan kebutuhan ekowisata.

d Zona Pengembangan : areal dimana berfungsi sebagai lokasi budidaya dan penelitian pengembangan ekowisata.

\section{Pendekatan pengelolaan ekowisata}

Untuk terkendalinya

pengelolaan ekowisata secara

profesional dibutuhkan manajemen/pengelolaan kawasan ekowisata yang berdasarkan kepada aspek-aspek Sumber Daya Manusia (man), seperti keuangan (money), aspek material, aspek pengelolaan/bentuk usaha (metode) dan aspek market (pasar). Kelima unsur tersebut dapat diorganisasikan dalam bentuk usaha Korporasi, Perseroan Terbatas (PT), Koperasi maupun Perorangan atau Corporate Manajemen.

\section{Pendekatan perencanaan kawasan} ekowisata

Perencanaan

kawasan

ekowisata dimaksudkan untuk menjawab beberapa pertanyaan terhadap unsur-unsur perencanaan yang menjadi daya dukung pengembangan dan pembinaan kawasan ekowisata, meliputi: Apakah tersedia potensi ekowisata dan memadai untuk dikembangkan; Apakah potensi ekowisata dimaksud dapat mendukung bagi pembangunan kepariwisataan berkelanjutan; Apakah ada segmen pasar untuk ekowisata; Apakah menurut perhitungan besaran investasi lebih tinggi daripada kerugian yang diperoleh dan Apakah masyarakat setempat dapat turut berpartisipasi dalam penyusunan perencanaan. Beberapa pertanyaan tersebut dapat dikembangkan sesuai dengan kebutuhan perencanaan.

\section{Pendekatan pendidikan ekowisata}

Ekowisata memberikan sarana untuk meningkatkan kesadaran orang akan pentingnya pelestarian dan pengetahuan lingkungan, baik wisatawan nusantara maupun mancanegara. Ekowisata harus menjamin agar wisatawan dapat 
menyumbang dana bagi pemeliharaan, keanekaragaman hayati yang terdapat di daerah yang dilindungi sebagai salah satu proses pendidikan memelihara lingkungan. Pendekatan pendidikan ekowisata harus bermula dari dasar, dan dimulai sejak anak-anak berada di tingkat taman kanak-kanak, sekolah dasar dan berlanjut ke jenjang yang lebih tinggi, oleh karena itu dibutuhkan semacam modul praktik yang dapat diberikan pengajarannya oleh setiap Pembina baik melalui pendidikan formal maupun pelatihan khusus.

\section{Pendekatan pemasaran}

Pendekatan

pemasaran

ekowisata lebih ditujukan dalam konsep pemasaran social dan pemasaran bertanggung jawab. Pemasaran sosial tidak hanya berupaya memenuhi kepuasan wisatawan dan tercapainya tujuan perusahaan (laba), tetapi juga dapat memberikan jaminan sosial sumber daya dan pelestarian lingkungan dan tata cara penanggulangan, perencanaan lingkungan, teknikteknik promosi harus mengarahkan kepada ajakan kepada wisatawan untuk berlibur dan beramal dalam pelestarian lingkungan serta mendidik wisatawan dan masyarakat berkiprah dalam kesadaran bahwa apa yang mereka saksikan dan alami, akan musnah dan hancur bilamana tidak dipelihara dan dilestarikan sejak awal pemanfaatan dan memperbaiki kerusakan lingkungan.

\section{Pendekatan organisasi}

Pendekatan dasar pembangunan berkelanjutan adalah kelestarian sumber daya alam dan budaya. Sumber daya tersebut merupakan kebutuhan setiap orang saat sekarang dan dimasa yang datang agar dapat hidup dengan sejahtera, untuk itu dibutuhkan pengorganisasian masyarakat agar segala sesuatu yang telah menjadi kebijakan dapat dibicarakan, didiskusikan dan dicari jalan pemecahannya dalam satu organisasi ekowisata yang bertanggung jawab terhadap kelangsungan pembinaan ekowisata di satu kota dan kabupaten di daerah tujuan wisata.

\section{METODE PENELITIAN}

Penelitian ini merupakan penelitian deskriptif kualitatif. Arikunto (2002:34) mengatakan bahwa "penelitian deksriptif kualitatif merupakan penelitian yang dimaksudkan untuk mengumpulkan 
informasi mengenai status atau gejala yang ada, yaitu keadaan gejala yang dikumpulkan dilapangan menurut apa adanya pada saat penelitian dilakukan". Jadi yang penulis lakukan untuk melaksanakan penelitiannya harus sesuai dengan kondisi saat sedang melakukan penelitian, sesuai dengan gejala yang ada.

Definisi Operasional dalam sebuah penelitian dimaksudkan untuk membatasi studi. Sehingga dengan pembatan studi tersebut akan mempermudah penelitian dan pengolahan data yang kemudian menjadi sebuah kesimpulan. Peneliti menentukan definisi operasional ini yaitu pemahaman atas gambaran rumusan masalah yaitu berupa :

a. Ekonomi, Sosial, Budaya

b. Ekowisata mangrove

c. Kondisi dan pola pemanfaatan lahan ecotourism mangrove

Sumber data dalam penelitian ini adalah benda atau orang yang dapat diamati dan memberikan data maupun informasi yang sesuai dengan fokus penelitian yang telah ditetapkan. Arikunto (2002:36) mengatakan bahwa yang dimaksud sumber data dalam penelitian adalah subjek dari mana data dapat diperoleh. Dari pendapat diatas, menjelaskan bahwa apabila peneliti menggunakan kuesioner atau wawancara dalam pengutipan datanya, maka sumber datanya disebut informan, yaitu orang-orang yang memberikan informasi atau menjawab pertanyaan-pertanyaan peneliti baik pertanyaan tertulis maupun lisan, apabila menggunakan teknik dokumentasi maka sumber data yang diperoleh itu berupa data primer dan data sekunder dari sumber-sumber data yang ada.

1 Data Primer

Data yang diperoleh melalui informan dengan cara melakukan Tanya jawab atau wawancara secara langsung.

2 Data Sekunder

Dalam penelitian ini yang menjadi sumber data sekunder adalah data yang diperoleh melalui beberapa sumber informasi yaitu berupa dokumen-dokumen yang berkaitan tentang Ecotourism dan Hutan Mangrove.

\section{ANALISIS DAN PEMBAHASAN}

Peneliti mengambil ekowisata yang berhubungan dengan hutan 
mangrove yang tumbuh di pesisir hingga delta sebuah kawasan. Hal ini tidak terlepas bahwa mangrove memiliki manfaat yang cukup banyak untuk kawasan pesisir dan ekosistem yang sangat berguna untuk keseimbangan alam yang belum banyak dikenal oleh masyarakat. Ekowisata mangrove diperkenalkan untuk kesadaran masyarakat untuk mengenal kembali alam dan pelingkupnya. Di sisi lain dengan adanaya ekowisata mangrove, masyarakat memiliki alternatif wisata yang tidak hanya mengandalkan sektor wisata di kawasan urban berupa pusat perbelajaan melainkan wisata alam. Ekowisata mangrove merupakan pilihan yang tepat untuk melepas penat bagi masyarakat kota yang dalam keseharian disibukkan dengan rutinitas. Ekowisata mangrove memiliki beragam kegiatan mulai dari pemancingan, menelusuri mangrove dengan perahu speed boat, menghirup udara segar alam hijau, serta kedekatannya dengan wisata bahari.

Pola penyebaran ekowisata mangrove untuk di Provinsi Kalimantan Timur cukup banyak. Peneliti melakukan beberapa lokasi mangrove yang cukup popular seperti Mangrove di teluk Balikpapan, Mangrove Delta Mahakam, dan Mangrove di Taman nasional Kutai. Kawasan mangrove tersebut memiliki keunggulan dalam pemeliharaan dan masuk ke konservasi yang sangat diperhatikan oleh masyarakat yang tergabung dalam komunitas sosial hingga pemerintah dan Korporasi besar.

Kawasan konservasi Mangrove yang sangat luas dan memiliki keanekaragaman hayati yang sangat unik adalah kawasan Delta Mahakam dan teluk Balikpapan. Apabila dilihat dari segi geografis, mangrove di kawasan Delta Mahakam merupakan mangrove yang berada di pesisir karena pintu masuk air laut ke Sungai Mahakam melalui daerah ini. Sejarah panjang kawasan Delta Mahakam telah lama terjadi sebelum zaman kemerdekaan. Kawasan delta Mahakam sebelum masa kemerdekaan telah ada 3 kampung tua yang didiami oleh penduduk asli yakni suku bugis yang sebagian besar hidup sebagai nelayan sejak generasi awal.

Zaman terus berganti dan era modern telah masuk mempengaruhi 
kehidupan masyarakat. Namun hal ini tidak membuat kearifan lokal masyarakat Delta Mahakam ikut tergerus dengan modernisasi. Kehidupan keseharian masyarakat masih mengandalkan sektor hasil laut dengan bermata pencaharian sebagai nelayan dan tambak ikan di sekitar Delta Mahakam. Lokasi yang cukup jauh serta sarana prasarana yang minim dari Kota dan Kabupaten sekitar tidak menyurutkan niat mereka untuk tetap tinggal dan menetap di kampung halaman. Masyarakat yang sudah lama tinggal dan menetap dapat dikatakan memiliki keterbatasan ekonomi dan sumber daya manusia yang minim. Berbeda kondisi ketika masyarakat pendatang yang notabene orang baru yang sukses mendiami kawasan tersebut dimana sebagian besar berasal dari Sulawesi Selatan. Masyarakat asli secara turun temurun dari generasi ke generasi telah lama mendiami serta paham sejarah dan kawasan yang telah lama mereka diami. Berbeda kondisi dengan masyarakat pendatang yang baru dan tidak tahu sejarah sehingga harus hati-hati dalam mengambil kebijakan agar tidak terjadi konflik di masyarakat.

Kearifan lokal masyarakat delta Mahakam terkenal sejak dahulu kala sebagai nelayan dan berladang. Kawasan ini dahulu hanya dapat diakses oleh perahu nelayan yang masuk ke Kota Samarinda. Masyarakat banyak melakukan perniagaan dengan menjual kelapa ketika air laut naik untuk menunjang jalannya perahu menyusuri Delta Mahakan hingga masuk ke Sungai Mahakam yang membelah kota Samarinda. Segi sumber daya manusia, masyarakat local dapat dikatakan cukup rendah sehingga masyarakat tidak paham regulasi dan tata kelola. Kecamatan yang dianggap agen pemerintahan di kawasan tersebut tidak mengetahui dan paham mengenai aturan dan regulasi dalam perambahan hutan. Konflik SDM bermula ketika kebiasaan masyarakat melakukan perambahan hutan dan memindahkan keramba ikan. Kejadian ini dibiarkan dan berlalu sehingga muncul peraturan.

Pada tahun 1999 - 2000 mulai muncul terkait surat garap masyarakat dalam perambahan hutan 
karena memiliki sanksi pidana. Dengan adanya UU pembiaran hutan maka masyarakat harus paham mengenai sanksi tegas agar hal ini tidak terus dibiarkan dan tidak saling menyalahkan antara masyarakat dengan pemerintah. Masyarakat perlu terus banyak belajar dari perjuangan dan proses yang selama ini dilakukan untuk memajukan kawasan Delta Mahakam. Masyarakat perlu melihat potensi besar dan pengembangan yang lebih lanjut (sustainable) dan secara keseluruhan mengenai budaya Delta mahakam.

Kegiatan masyarakat sekitar kawasan Delta Mahakam dan konservasi mangrove tidak terlepas dari aktivitas air, sungai, muara, dan delta. Hal ini memiliki persoalan yang mendalam mengenai limbah air yang terurai pada ekosistem dan direduksi sebelum ke laut agar stabil. Perlu di ketahui bahwa masyarakat Kota Samarinda dan Kabupaten yang berhubungan langsung dengan aliran Delta Mahakam perlu untuk mengelola Kegiatan rumah tangga dan aktivitas masyarakat dalam memanfaatkan sumber air yang ramah lingkungan dan tidak mengotori air dengan sampah atau limbah beracun hasil industri dan rumah tangga. Pelaksanaan edukasi terkait akuakultur untuk mengubah pola pikir, kelola usaha, kegiatan ramah lingkungan agar menjaga kualitas air. Apabila kualitas air buruk maka berakibat pada rusaknya ekosistem.

Kawasan delta Mahakam adalah kekayaan alam yang dimiliki Kalimantan Timur yang pada zaman orde baru tidak ada sosialisasi mengenai penetapan Delta. Penguasa pada zaman itu masih fokus untuk melakukan pembangunan yang bersifat sentralisasi di ibukota Negara. Kawasan delta Mahakam disamping kekayaan alam, kawasan ini memiliki kekayaan dari segi mineral yang terkandung di dalamnya setelah beberapa korporasi besar berada di sekitarnya. Korporasi besar memiliki andil dan kepentingan karena adanya bisnis yang dijalankan sehingga perlu pendekatan yang berbeda dengan masyarakat agar tidak menimbulkan konflik. Korporasi melaksanakan kegiatan yang ramah lingkungan dan memiliki sumbangsih besar dalam pemberdayaan pengelolaan kawasan namun tidak menguasai. 


\section{Ekonomi Sosial Budaya}

Ekowisata memiliki dampak ekonomi yang cukup besar dalam menghasilkan pendapatan bagi warga sekitar kawasan hutan mangrove. Hal ini dikarenakan kunjungan wisata yang bersifat multiplyer effect atau perputaran ekonomi dimana masyarakat selain berwisata juga melakukan pembelian barang / produk yang menjadi ciri khas lokasi wisata. Dapat dicontohkan ketika masyarakat pergi ke Delta Mahakam dan kawasan mangrove teluk Balikpapan maka mereka disuguhkan pemandangan alam dengan menyewa perahu wisata sehingga menghasilkan pendapatan bagi masyarakat sekitar. Masyarakat pulang dari lokasi ekowisata dirasa kurang lengkap tanpa membawa buah tangan khas daerah setempat.

Tantangan wisata ada misalnya ekowisata wilayah Delta Mahakam berbeda dengan kawasan ekowisata mangrove Balikpapan yang mudah dijangkau. Delta Mahakam yang merupakan wilayah yang luas dan terbagi dalam zonasi wilayah tertentu membuat masyarakat masih enggan mengunjungi kawasan yang unik ini karena terlampau jauh. Masyarakat adalah konsumen dimana mereka akan mempertimbangkan kegiatan wisata dan petualangan yang lokasinya mudah dijangkau.

Pemerintah ingin menggalakkan Ekowisata yang memiliki tujuan khas dan pilihan yang tepat dalam beragam alternative destinasi pariwisata yang berbeda dan belum pernah dikunjungi sebelumnya. Perhatian khusus pemerintah dalam ekowisata yakni konservasi terhadap lingkungan yang bersih dan cagar alam terpelihara. Mengunjungi ekowisata mangrove, wisatawan dihadapkan pada jalur track jembatan kayu ulin yang kuat dimana kiri dan kanan terdapat pemandangan hutan mangrove dan bakau disertai flora fauna yang hidup liar di sekeliling. Hal itu baru jalur darat, belum termasuk hutan bakau yang harus dilalui melalui jalur air dimana pengunjung diajak untuk mengarumgi laut dengan menggunakan speed boat yang disekitarnya terdapat akar dan tumbuhan-tumbuhan hijau.

Delta mahakan selama ini telah disentuh oleh berbagai pihak dalam kegiatan sosial ekonomi untuk menumbuhkembangkan kegiatan- 
kegitan yang bersifat produktif. Salah satunya adalah Yayasan Mangrove Lestari yang melaksanakan Proyek kegiatan di Delta Mahakam bekerjasama dengan NGO dari Perancis yakni Planet Urgence. Kegiatan Yayasan Mangrove lestari sebagai lembaga yang bergerak di bidang sosial dengan melaksanakan kegiatan edukasi kepada masyarakat sekitar Delta Mahakam untuk mengubah cara tambak yang ramah liungkungan. Dana kegiatan lembaga ini berasal dari salah satu NGO Perancis yang diilhami oleh salah satu warga Negara Perancis yang pada saat itu datang mengunjungi delta Mahakam untuk berwisata dan melihat potensi kearifan lokal kawasan yang unik dan menakjubkan karena baru pertama kali orang Perancis tersebut menyusuri desadesa di kawasan Delta Mahakam melalui jembatan-jembatan kayu dan ciri khas rumah-rumah rakit yang menjorok ke laut. Ciri khas dan keunikan wilayah Delta Mahakan dan Teluk Balikpapan menjadikan wisatawan berdecak kagum walau lokasi jauh namun kepuasan batin di dapatkan oleh pengunjung.
Kawasan Mangrove baik di Balikpapan maupun di Delta mahakan merupakan kawasan yang unik. Masyarakat dapat melihat beragam kekayaan ekosistem yang saling menyatu dengan alam. Hutan tanaman alam menyatu dengan laut yang di dalamnya terdapat fauna endemik Kalimantan yakni bekantan, ekonomi masyarakat yang mengandalkan sektor laut dengan bermata pencaharian sebagai nelayan dan menambak ikan. Masyarakat pelosok yang ramah dan terbuka terhadap pendatang yang berkunjung, pemukiman yang dilalui dengan jembatan kayu yang ditopang papan dan tongkat kayu yang kokoh menghubungkan wilayah satu dengan wilayah lain. Sebuah lokalitas yang berbaur menjadi satu. Hal ini membuat beberapa lembaga dan institusi memberikan perhatian khusus berupa dana CSR, volunteer, dan NGO luar negeri memilih kawasan Mangrove di Delta Mahakam sebagai kawasan konservasi.

Masyarakat dilibatkan dalam proses rehabilitasi mangrove di lahan terbuka, apabila bagi pihak bapakbapak memilih berlayar untuk 
mencari ikan dan menambak. Para ibu-ibu diajarkan untuk lebih produktif lagi mengelola sektor mikro yang belum pernah dilakukan untuk menambah penghasilan yakni dengan membuat panganan dan kerajianan yang berasal dari wilayah setempat seperti membuat kerupuk, amplang, abon dari olahan ikan melalui dana bantuan CSR korporasi dan NGO.

Masyarakat setempat telah memiliki tambak yang ekstensif dan tradisional. Hal ini peran NGO dan CSR sebagai tanggungjawab sosial dan menumbuhkan kesadaran masyarakat terhadap alam maka dibuatlah kegiatan berupa pendampingan, tata cara, dan aturan dalam menambak yang benar. Interaksi antara penduduk lokal dan wisatawan terjadi sehingga wisata sosial turut dikembangkan melalui aktivitas sosial yang dilakukan warga sekitar. Pengunjung bersama warga diajak untuk berlatih menanam mangrove dan memilih antara mangrove yang baik dan rusak. Pengelola juga dapat mengajak pengunjung untuk melihat tata ruang dan bentang alam yang berguna untuk edukasi, rekreasi, dan penelitian.

\section{Kelestarian Ekosistem}

Melalui tumbuhan nipah, bakau, mangrove yang akarnya kuat memiliki manfaat bagi formasi air laut yang akan masuk ke sungai di delta karena air laut akan diikat oleh akar-akar. Ekosistem akar menggantung mengikat tanah supaya tidak mudah kena gempuran air serta mengikat tanah supaya tidak terurai. Dengan kata lain akar-akar dari nipah, bakau, dan mangrove akan menjadi greenbelt (sabuk hijau) sebagai penahan gelombang yang fungsi dan manfaatnya berasal dari alam. Secara ekonomis mangrove perlu ditanam sebagai penahan masuknya air laut ke daratan. Melalui hutan mangrove yang tumbuh di delta Mahakam, air laut yang masuk ke sungai mahakan akan terurai dan merubah formasinya

Pembangunan berkelanjutan mengenai sektor mangrove terus dilakukan bukan sekedar mencari peluang dan potensi alam yang berguna bagi hajat hidup orang banyak semata. Di sisi lain untuk meminimalisir masalah di masa depan terkait lingkungan seperti isu 
pemanasan global dunia, bencana alam yang mengakibatkan pergeseran lempeng tektonik yang berakibat gempa dan tsunami, anomali cuaca, dan beragam faktor alam lainnya. Kegiatan yang ramah lingkungan sangat diperlukan agar setiap individu sadar bahwa kelestarian lingkungan diperoleh dari hasil yang selama ini kita tanam.

Kalimantan Timur sudah selayaknya memiliki kawasan konservasi dan gerakan penghijauan untuk kelestarian. Beberapa tahun terakhir Kalimantan Timur sedang mengalami problematika berupa kasus kerusakan alam akibat pertambangan. Wilayah kita memang kaya akan tambang batu bara namun tambang tersebut tidak dapat diperbaharui dan menyisakan beragam problematika yang belum dapat terselesaikan. Reklamasi dan penutupan lubang tambang merupakan jalan yang harus ditempuh namun tidak semua pihak pengusaha tambang melakukannya. Proses alam melalui Tambang batu bara vellet dari kayu membutuhkan waktu yang lama. Di sisi lain energy fosil tidak diperbolehkan lagi karena batu bara tidak sustainable sehingga masyarakat perlu melakukan kegiatan lingkungan dengan membuka lahan, sumur, dan ladang baru. Gambaran tersebut memberikan kesadaran kepada masyarakat bahwa lingkungan memiliki dampak yang signifikan bagi alam. Ekplorasi batu bara yang membuat nilai ekonomi Kalimantan Timur meningkat namun menyisakan pekerjaan dan problematika berupa dampak lingkungan yang kurang baik sehingga menyadarkan beberapa pihak untuk turut mewadahi kegiatan edukasi lingkungan melalui penanaman dan pemeliharaan mangrove secara sederhana melalui pemberdayaan ekonomi masyarakat sekitar ekowisata mangrove, sinergi antara pemerintah dan stakeholder swasta dilakukan untuk melakukan rehabilitasi wilayah dengan penanaman pohon, tanam tebang diciptakan lagi. Hal ini sesuai dengan cita-cita dari UPT Balai besar KDHTK, DLH Provinsi, Dinas Kehutanan untuk melaksanakan program Sustainable Development Internastional (SDGIS Program).

\section{Ekowisata Mangrove}

Ekowisata merupakan ekonomi alternatif bagi masyarakat yang 
menginginkan pariwisata yang berbeda karena masyarakat akan berada dekat dengan alam dan melihat secara langsung pola ekosistem makluk hidup yang saling melengkapi karena adanya rantai makanan. Semua lapisan masyarakat perlu medukung keberadaan ekowisata mangrove sebagai investasi kehidupan alam untuk masa depan yang lebih baik. Pengembangan regulasi dan kerjasama pemerintah terus dilakukan walau berbenturan dengan problem yang terjadi di lapangan.

Perkembangan informasi dan arus komunikasi perlu ditingkatkan kepada masyarakat luas karena popularitas dan manfaat mangrove masih asing bagi masyarakat awam di luar lingkungan ekowisata mangrove. Keterbukaan infromasi membawa dampak kepada masyarakat luas dalam menawarkan beragam keunggulan-keungulan bahkan hal yang menarik dari aktivitas

\section{Kegiatan Pelestarian Mangrove}

Kementeian melalui balai besar UPT melakukan beragam perencanaan yang matang dalam implementasi kegiatan mangrove di
Delta Mahakam walaupun ini juga terkait dengan anggaran dari pemerintah pusat. Kementerian bekerjasama dengan Provinsi dan kota berusaha untuk melakukan koordinasi dan kerjasama dalam mengembangkan potensi mangrove yang ada di sekitar Teluk Balikpapan dan Delta Mahakam.

Hal ini juga dilakukan dengan Taman Nasional Kutai Bontang dalam tukar pendapat dan saran dalam mengelola profil dan penelitian. Potensi mangrove dari segi riset / penelitian mendalam bagi Kementerian bertujuan untuk peta semua zonasi yang memiliki potensi besar bagi pengetahuan seperti biodiversity, soil, tapak naih, sosial mapping, peta kelola, resolusi konflik, ekonomi masyarakat. Kerjasama dilakukan dengan Dinas provinsi dan DLH untuk mengali potensi wisata, memantau lingkungan, zonasi pemanfaatan lahan, penyesuaian dengan hukum dan atauran UU yang berlaku, serta pusat informasi mangrove. Kerjasama yang terjalin dan koordinasi dilakukan melalui pengembangan teknis secara terstruktur dan pembagian tugas dan 
tangungjawab agar tidak tumpang tindih.

Beberapa kegiatan aksi lingkunan dilakukan dengan tujuan melestarikan lingkungan dan mengelola aktivitas yang memiliki dampak baik dan buruk terhadap keseimbangan alam. Kementerian bersama CSR dan NGO mellaui beragam penelitian citra permukaan yang didalamnya terdapat $50 \%$ gambaran citra terbuka yang didalamnya terdapat aktivitas tambak. Perlunya edukasi dan sosialisasi kepada masyarakat untuk tidak membuat jarring yang menjorok ke sungai atau laut. Di lain pihak rumah-rumah warga di 15 desa di Delta Mahakam menjorok ke laut. Peristiwa alam seperti abrasi air laut yang terjadi pendangkalan di hulu sungai sehingga mempersulit kapal laut besar menyandarkan kapal di pelabuhan.

Setiap kegiatan yang dilakukan masing-masing instirtusi baik Balai besar KDHTK, DLH, Pemprov dinas kehutanan berkoordinasi dan melaksankaan sosialisasi kepada rekada rekan dalam sinergi kebijakan dan tanggungjawab. Namun perlu digarisbawahi bahwa dokumen peta dan inventarisasi tidak tumpang tindih peranannya karena pengembangan dan potensi yang dilakukan sesuai dengan potensi rencana yang telah disepakati. Factor pendukung dari masing-masng institusi adalah terkait program, sinergi, tim, sarana prasarana, teknis implementasi, serta batasan dalam kebijakan dilakukan secara bersama. Disamping kekuatan yang dimiliki oleh masing-masing institusi, ada keterbatasan dalam manajemen lapangan yakni anggaran yang terbatas, sarana prasarana yang harus dilalui ketika terjun ke lapangan, dukungan rencana dokumen karena harus lengkap pada saat eksekusi di lapangan.

\section{KESIMPULAN DAN SARAN}

\section{Kesimpulan}

1. Pengembangan

Ekowisata

(Ecotourism) Di Kawasan

Konservasi Hutan Mangrove dilakukan oleh masyarakat setempat dengan di dukung oleh pemerintah, NGO, dan pihak swasta melalui berbagai program yang membantu masyarakat setempat untuk terus produktif dalam melestarikan lingkungan alam dan memelihara kawasan 
mangrove sebagai masa depan lingkungan alam yang lebih baik

2. Kebijakan dan peran institusi dalam Pengembangan Ekowisata (Ecotourism) Di Kawasan Konservasi Hutan Mangrove adalah ekowisata meningkatkan taraf hidup masyarakat setempat apabila dikelola secara baik dan benar. Peran institusi dan lembaga banyak memberikan sumbangsih dalam memberikan pendampingan dan monitoring terhadap setiap kegiatan sosial dan kemasyarakatan. Wujud nyata sumbangsih masyarakat terhadap kehidupan alam melalui mangrove adalah melakukan sosialisasi dan aksi dalam penanaman mangrove, bersama komunitas mengadakan pendampingan dalam pengolahan hasil laut berupa ikan.

\section{Saran}

Kesimpulan penelitian di atas, maka saran peneliti yakni

1. Yayasan Mangrove beserta NGO lebih banyak turun ke lapangan dan implementasi kegiatan dilakukan secara konsisten. Berbeda dengan pemerintah dan swasta karena terbentur dengan structural di pekerjaan dan dana yang digunakan cukup terbatas, berbeda dengan swasta yang kucuran dana dipakai hanya untuk kepentingan perusahaan. Perlu adanya monitoring dan evaluasi secara berkala agar tidak saling klaim wewenang dan tanggungjawab

2. Kawasan pesisir lokasi yang kaya akan mineral sehingga perlu adanya tata kelola dalam mengambil kebijakan atau aturan yang jelas antara pemerintah dan stakeholder agar tidak bersingungan dan memicu konflik dengan pihak lain.

\section{DAFTAR PUSTAKA}

Arikunto, Suharsimi. 2002. Prosedur Penelitian. Rineka Cipta Jakarta.

Dirawan, 2003. Pengantar Ekowisata. PT. Gramedia Pustaka Utama : Jakarta.

Emma Hijriati dan Rina Mardiana. Pengaruh Ekowisata Berbasis Masyarakat Terhadap Perubahan Kondisi Ekologi, Sosial Dan Ekonomi Di Kampung Batusuhunan, Sukabumi Community Based Ecotourism influence the condition of Ecology, Social, and Economic Batusuhunan village, Sukabumi Departemen Sains Komunikasi dan Pengembangan Masyarakat, Fakultas Ekologi Manusia, IPB ISSN : 2302 - 7517, Vol. 02, No. 03 
Fandeli C dan Nurdin M. 2005. Pengembangan Ekowisata Berbasis Konservasi di Taman Nasional. Fakultas Kehutanan Universitas Gajah Mada: Jakarta

Fandeli, Chafid dan Mukhlisson, 2000. Perencanaan Lingkungan. Gadjah mada University Press : Yogyakarta. 